\title{
Estimating the unconfined yield strength of coal in the case of longwall coal mining with hanging wall top caving
}

\section{Določanje kompresijske trdnosti premoga pri odkopavanju $s$ širokočelno metodo in zaruševanjem krovnine}

\author{
Damjan Hann ${ }^{1}$,* \\ ${ }^{1}$ University of Ljubljana, Faculty of Natural Sciences and Engineering, Aškerčeva 12, 1000 Ljubljana, Slovenia \\ *damjan.hann@ntf.uni-lj.si
}

\begin{abstract}
This study presents an innovative approach for determining the unconfined yield strength $\sigma_{c}$ during the excavation of coal from the earth's crust by using an equipment that was developed for measuring the mechanical properties of bulk materials stored in silos. Highly productive excavation of coal with a hanging wall top caving leads to intensive deformations in the hanging wall and the broken coal can be considered as bulk material. In this research, the shear tester Johanson Hang-Up Indicizer was used to measure the unconfined yield strength of the tested samples, even though such a tester cannot produce stress-strain conditions similar to those occurring during the excavation. An attempt was made to estimate the real unconfined yield strength of broken coal deep under the surface through a combination of measured data and extrapolation.
\end{abstract}

Key words: unconfined yield strength, coal, Johanson Hang-Up Indicizer

\section{Izvleček}

Članek predstavlja inovativen pristop $\mathrm{k}$ določevanju kompresijske trdnosti $\sigma$ pri odkopavanju premoga $\mathrm{v}$ zemeljski skorji, in sicer $\mathrm{z}$ uporabo opreme, ki je bila razvita za potrebe določanja mehanskih lastnosti sipkih materialov, skladiščenih v silosih. Visokoproduktivno odkopavanje premoga z zaruševanjem krovninskih plasti ima za posledico intenzivne deformacije krovninskih plasti, zato lahko porušeno hribino obravnavamo kot sipek material. $\mathrm{V}$ raziskavi je bil uporabljen strižni tester Johanson hang-up indicizer $\mathrm{z}$ namenom določanja kompresijske trdnosti testnih vzorcev, čeprav ta tester ne more posnemati napetostno-deformacijske pogoje, ki se pojavljajo pri odkopavanju. Kljub temu dejstvu se je poskušalo s kombinacijo merjenih podatkov in ekstrapolacije določiti kompresijsko trdnost zarušenega premoga globoko pod površjem.

Ključne besede: kompresijska trdnost, premog, Johanson hang up indicizer 


\section{Introduction}

Excavation of coal using the highly productive longwall coal mining and hanging wall top caving approach leads to intensive structural changes in the surrounding layers. Due to deformations in the hanging wall, the behaviour of broken layers can be considered similar to that of the bulk material. Bulk materials have the ability to flow, and this property is also used to get coal from the overburden (Figure 1).

In the past, the behaviour of bulk solids was the subject of research mainly due to the necessity of obtaining knowledge on the mechanical properties, or the so-called flow properties, of bulk solids in order to design silos and feeders and to solve problems connected to storage of bulk materials in silos, especially problems with the flow from silos. The behaviour of bulk solids is dependent on various factors. Table 1 shows a number of important characteristics [1] identified by the US Conveyor Equipment Manufacturers Association (CEMA) as being necessary for the complete examination of the behaviour of bulk materials.

Table 1: Characteristics of bulk materials required for selection or dimensioning of conveying equipment

\begin{tabular}{cc}
$\begin{array}{c}\text { Density/bulk } \\
\text { density }\end{array}$ & Coating tendency \\
\hline Dustiness & Attritability \\
\hline Size/size distribution & Electrical properties \\
\hline Plasticity & Hygroscopicity \\
\hline Particle shape & Compressibility \\
\hline Aeratability & Moisture content \\
\hline Flow properties & Hardness \\
\hline Stickiness & $\begin{array}{c}\text { Frictional } \\
\text { properties }\end{array}$ \\
\hline
\end{tabular}

This article presents an innovative approach for determining the mechanical properties during the excavation of coal beneath the ground surface, by using equipment developed to measure the mechanical properties of bulk materials stored in silos and bins.

In many technical applications, a consolidated bulk solid at rest has to be set to flow, i.e. the yield point of the bulk solid has to be over- come [2]. Such a case is silo emptying (Figure 2), wherein the material is often packed firmly against the wall and the stream is confined to the middle portion (core) [3]. A similar case is the top caving process with broken coal, which has to be set to flow from the upper part into the open space close to the hydraulic support system. In both cases, the unconfined yield strength has to be overcome to allow material to flow as a granular material.

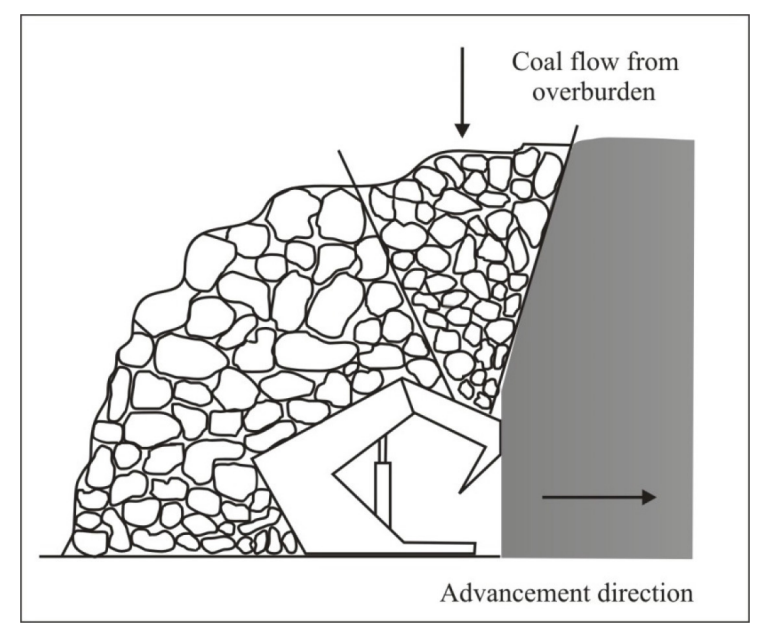

Figure 1: Process of excavation of coal using highly productive longwall coal mining and hanging wall top caving

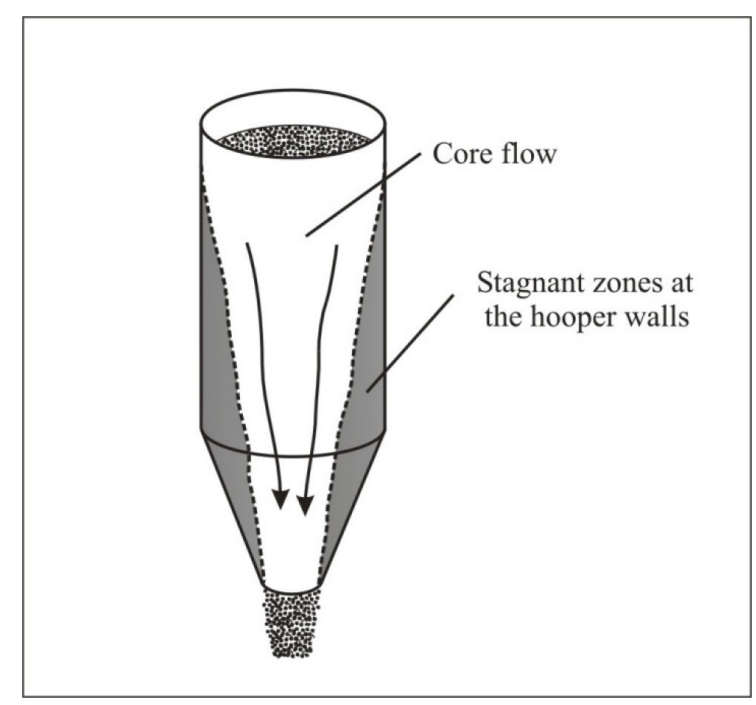

Figure 2: Funnel flow from silo ${ }^{[4-6]}$

\section{Materials and methods}

To describe the unconfined yield strength $\sigma_{c}$ Figure 3 shows a hollow cylinder (with frictionless walls) filled with a cohesive bulk solid, 
a.

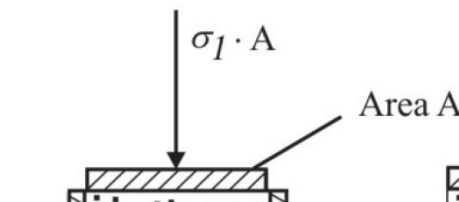

c.

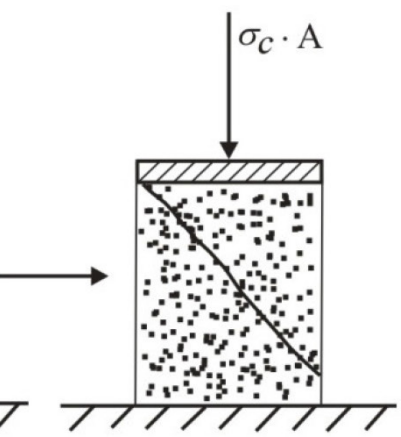

Figure 3: Measurement of unconfined yield strength of bulk material ${ }^{[7]}$.

A. Consolidation

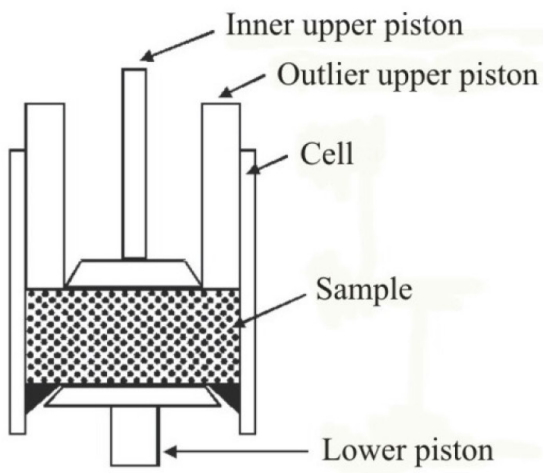

C.

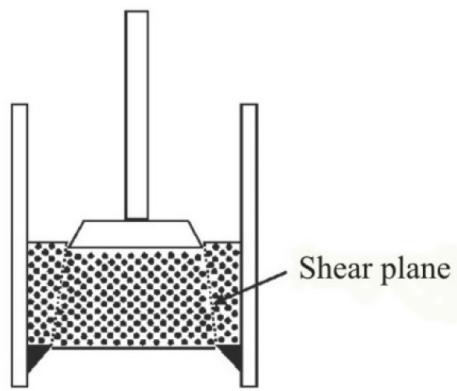

B.

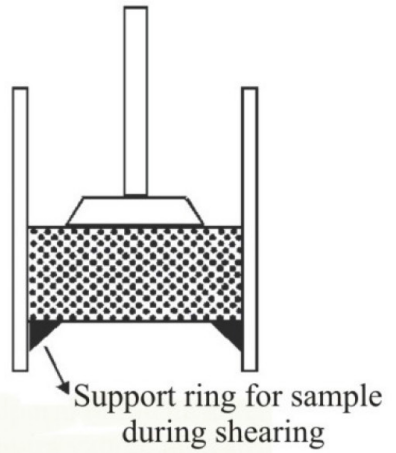

D. After failure

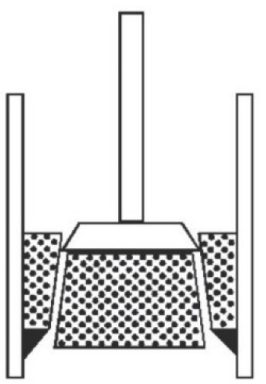

Figure 4: Principle of measurement of the unconfined yield strength using the Johanson Hang-Up Indicizer

which is exposed to consolidation stress $\sigma_{1}$. The cylinder is removed after consolidation and the sample of cylindrical bulk solid is exposed to an increasing compressive stress till the specimen breaks or flows. The stress acting at failure is called the unconfined yield strength, $\sigma_{c^{*}}$

In reality, such a simple test cannot be easily used to measure the unconfined yield strength of bulk solids. This is the reason why so-called shear testers such as the Johanson Hang-Up Indicizer are used to measure the flow properties of bulk solids. Unconfined yield strength, $\sigma_{c}$ measured with a Johanson Hang-Up Indicizer, is calculated [8] from the following expression: where $F$ is the measured failure force acting on the sample's cylindrical surface in the vertical 


$$
\sigma_{c} \approx \frac{2,2 \cdot F}{\pi \cdot H \frac{D_{u}+D_{l}}{2}}(P a)
$$

direction, $H$ is the height of the sample and $\mathrm{D}_{u}$ and $\mathrm{D}_{l}$ are the diameters of the inner upper and lower pistons.

The measurement procedure with the Johanson Hang-Up Indicizer requires the operator to fill and weigh the measurement cell with the sample to be tested. The cell is then placed in the Hang-Up Indicizer, where the sample is first consolidated and then failed (Figure 4), so that the internal computer can calculate and display the result on the screen.

Research on the unconfined yield strength of tested samples was conducted using the Johanson Hang-Up Indicizer, which is otherwise used to determine the unconfined yield strength of bulk materials with particle size up to about $5 \mathrm{~mm}$ in diameter, at vertical stresses up to $170 \mathrm{kPa}$. At this point, a complex multifaceted problem appears. This device is not intended to research the stress-strain conditions occurring during the excavation of mineral resources in the earth's crust but mainly for research in relation to the storage of bulk materials in silos, although we tried, with certain assumptions based on experience, to use the device to estimate the "in situ" data on unconfined yield strength of broken coal deep under the surface. The vertical stresses that appear during the use of the longwall mining method are especially due to the great depths of the mines, much higher than those that can be applied with the Johanson Hang-Up Indicizer or even those that appear in the case of storage in silos.

The problem of being unable to provide the appropriate stresses was solved by measuring the unconfined yield strength of samples at different vertical consolidation stresses within the capabilities of the device and by searching for possibilities of transferring the information obtained to real conditions.

With the aim of determining the unconfined yield strength of coal, the following samples were prepared by crushing and milling:

- $0-100 \mathrm{~mm}$

- $100-315 \mathrm{~mm}$

- 315-630 mm

- $630-1,250 \mathrm{~mm}$

- $1,250-3,150 \mathrm{~mm}$

- $3,150-5,000 \mathrm{~mm}$

In the process of longwall coal mining with top caving, the coal is flown from the hanging wall as both larger pieces of coal and a fine powder. To follow these conditions, the mixtures were prepared with $30 \%$ of fine particles of size fraction $0-100 \mathrm{~mm}$ and $70 \%$ of respective coarse fraction.

\section{Results and discussion}

Measurements of unconfined yield strength were conducted at the following consolidation stresses:

- $\sigma_{1 a}=10 \mathrm{kPa}$

- $\sigma_{1 b}=50 \mathrm{kPa}$

- $\sigma_{1 c}=100 \mathrm{kPa}$

- $\sigma_{1 d}=170 \mathrm{kPa}$

The data presented in Table 2 were obtained (each value is the average of two measurements):

The data obtained formed the basis for the graph shown in Figure 5.

Table 2: Measured unconfined yield strengths for different particle sizes and consolidation stresses

\begin{tabular}{ccccc} 
Mean particle & \multicolumn{4}{c}{ Unconfined yield strength $\boldsymbol{\sigma}_{c}$ (Pa) } \\
\cline { 2 - 4 } size $(\mathbf{m m})$ & $\sigma_{1 a}=10 \mathrm{kPa}$ & $\sigma_{1 b}=50 \mathrm{kPa}$ & $\sigma_{1 c}=100 \mathrm{kPa}$ & $\sigma_{1 d}=170 \mathrm{kPa}$ \\
\hline 0.05 & 865 & 3,965 & 7,340 & 15,033 \\
\hline 0.473 & 373 & 1,433 & 3,334 & 7,980 \\
\hline 0.94 & 315 & 1,134 & 2,532 & 6,004 \\
\hline 2.2 & 190 & 798 & 1,779 & 4,248 \\
\hline 4.08 & 235 & 370 & 883 & 2,723 \\
\hline
\end{tabular}




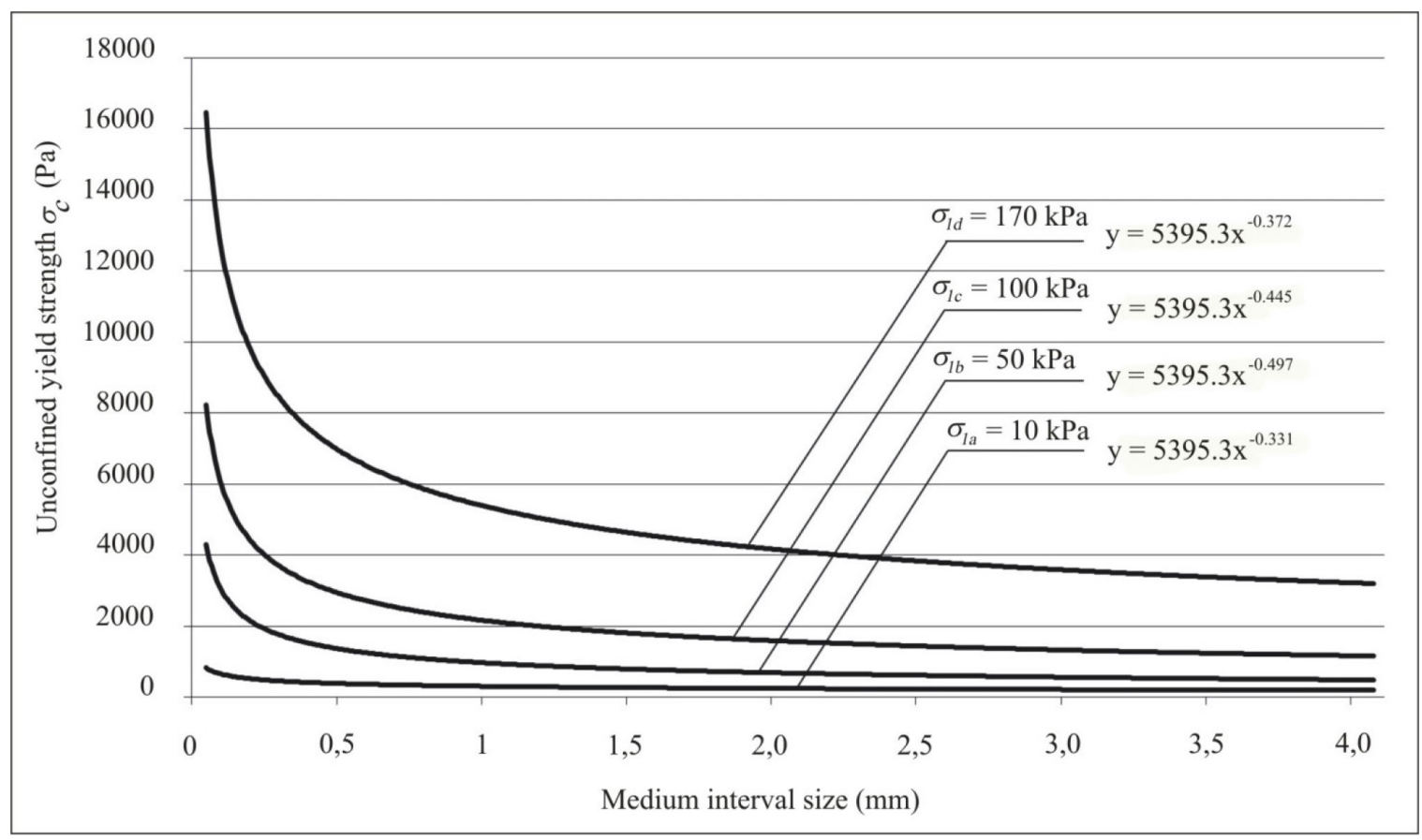

Figure 5: Unconfined yield strength of coal samples versus the medium interval size of coal particles.

The next step was to draw the flow function. Figure 6 shows some of the possibilities for the behaviour of bulk materials.

Figure 6 shows, besides others, flow functions $\mathrm{A}$ and $\mathrm{B}$ for bulk materials. Flow function $\mathrm{A}$ very often represents the typical degressive increase of the unconfined yield strength $\sigma_{c}$ with increasing consolidation stress $\sigma_{c^{*}}$. The flow function $B$ with progressive increase occurs somewhat less frequently.

On the basis of the equations from Figure 5, the values of the unconfined yield strength $\sigma_{c}$ were calculated for the bulk material with pieces of coal having $0.5 \mathrm{~m}$ diameter.

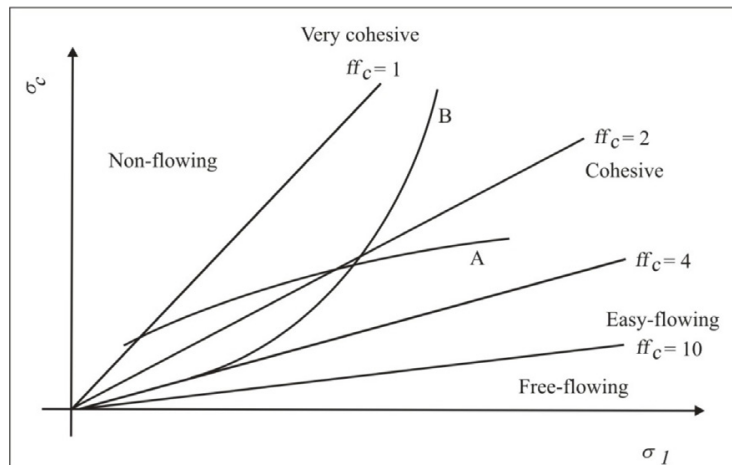

Figure 6: Unconfined yield strength versus consolidation stress; flowability is better with larger $\mathrm{ff}_{c^{\prime}}$ where $\mathrm{ff}_{c}$ is the ratio between $\sigma_{1}$ and $\sigma_{c}{ }^{[9]}$
Table 3: Calculated values of the unconfined yield strength $\sigma_{c}$ for coal pieces with $0.5 \mathrm{~m}$ diameter

\begin{tabular}{cc}
$\boldsymbol{\sigma}_{\mathbf{1}}(\mathbf{P a})$ & $\boldsymbol{\sigma}_{\boldsymbol{c}}(\mathbf{P a})$ \\
\hline 10,000 & 39.1 \\
\hline 50,000 & 44.1 \\
\hline 100,000 & 136.2 \\
\hline 170,000 & 534.6 \\
\hline
\end{tabular}

The data were plotted on a graph of $\sigma_{1}$ vs $\sigma_{c}$ (Figure 7).

Figure 7 shows that the tested coal is similar to the bulk material with function B in Figure 6 in terms of its flow function, with a progressive in-

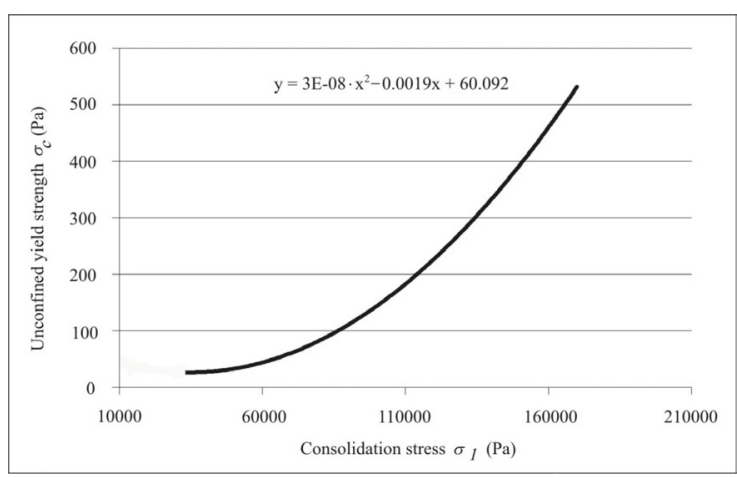

Figure 7: Non-linear correlation between vertical consolidation stress $\sigma_{1}$ and unconfined yield strength $\sigma_{c}$ for lignite. 


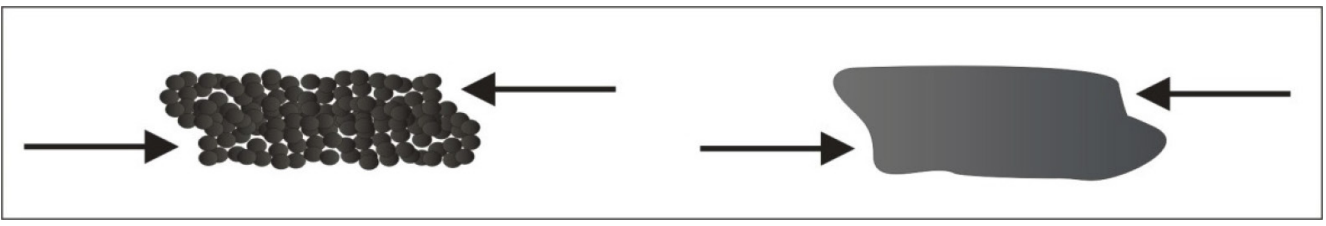

Figure 8: Comparison of shear of bulk material and shear of intact massif.

crease in the unconfined yield strength. This is the reason for the frequent occurrence of jams when broken coal is set to flow from the overburden.

The next step is to calculate the consolidation stress $\sigma_{1}$ that acts on the layers of coal in the hanging wall. The following conditions were assumed:

- Density of coal: $\rho_{c}=1,300 \mathrm{~kg} / \mathrm{m}^{3}$

- Coal mine depth: $H=400 \mathrm{~m}$

Taking into account the assumed density and depth, consolidation stress $\sigma_{1}$ is approximately represented as follows:

$\sigma_{1}=\rho_{c} \cdot H \cdot g(\mathrm{~Pa})$

$\sigma_{1}=1300 \frac{\mathrm{kg}}{\mathrm{m}^{3}} \cdot 400 \mathrm{~m} \cdot 9,81 \frac{\mathrm{m}}{\mathrm{s}^{2}}$

$\sigma_{1} \cong 5.1 \mathrm{MPa}$

Using the equation obtained for flow function in Figure 7, the unconfined yield strength of lumps of coal with $0.5 \mathrm{~m}$ diameter and exposed to consolidation stress $\sigma_{1}=5.1 \mathrm{MPa}$ can be calculated as follows:

$\sigma_{c}=3 \cdot 10^{-8} \sigma_{1}^{2}-0.0019 \cdot \sigma_{1}+60.092$

$\sigma_{c}=3 \cdot 10^{-8} \cdot\left(5.1 \cdot 10^{6}\right)^{2}-0.0019 \cdot 5.1 \cdot 10^{6}+60.092$

$\sigma_{c}=0.77 \mathrm{MPa}$

\section{Conclusions}

The unconfined yield strength of $50 \mathrm{~cm}$-sized pieces of coal, which are considered as bulk material and possess flow characteristics of the parent material regardless of their size, is in this case, at given density and depth of coal, about $0.8 \mathrm{MPa}$.
Value itself is not as important as is the fact that it is possible, when dealing with the stress-strain conditions and finding appropriate technological solutions for the extraction of coal from the overburden, due to the similarity of the processes, to apply the knowledge and equipment normally used for determination of stress-strain conditions in case of storage of bulk materials in silos.

It should be noted that in case of the unconfined yield strength, there is a shear of unloaded and unsupported sample, which was previously consolidated. This is the essential difference as compared with the measurement of shear strength in cases in which there is a shear of the loaded sample. It is also necessary to draw attention to the fact that the shear strength of the intact massif is one thing, but the shear strength of the broken material, which can be considered as bulk material, is a completely different thing (Figure 8).

Researching and understanding the influence of the different properties of particles on the unconfined yield strength at hanging wall top caving, where coal needs to be set to flow from the overburden, offers the possibility for the appropriate response with the aim to avoid frequent jams in the overburden. Relatively simple procedures such as drilling boreholes in the overburden for drying out the coal, for instance, is among many options that may be decided on the basis of the understanding of the mechanics of bulk materials.

\section{References}

[1] CEMA (1971): Screw Conveyors Handbook No. 350. Washington, USA: Conveyor Equipment Manufacturers Association, $140 \mathrm{p}$.

[2] Schulze, D. (2006): The behaviour of powders and bulk solid, renewed 7/7/2006 [cited 3/24/2016]. 
Available on: <http://www.dietmar-schulze.de/ grdle1pr.html>.

[3] Stepanoff, A.J. (1969): Gravity Flow of Bulk Solids and Transportation of Solids in Suspensions. New York: John Wiley \& Sons 1969; $191 \mathrm{p}$.

[4] Schulze, D. (2006): Stresses in Silo, renewed 7/7/2006 [cited 4/5/2016]. Available on: < http://www.dietmar-schulze.de/spannepr.html > .

[5] Van der KOOI, P.J. (1997): Silo design: Well Begun is Half Done. Powder Handling \& Processing, 9 (4), pp. 326-329.

[6] Arnold, P.C. (2001): Some Observations on the Importance of Particle Size in Bulk Solids Handling. Powder Handling \& Processing, 13 (1), pp. 35-40.

[7] Schulze, D. (2014): Flow Properties of Powders and Bulk Solids and Silo Design for Flow, renewed in 2014 [cited 3/24/2016] Available on: <http://www.dietmar-schulze.de/powtve.pdf $>$.

[8] Schwedes, J. (2000): Testers for measuring flow properties of particulate solids. Powder Handling \& Processing, 12 (4), pp. 337-354.

[9] De Silva, S.R. (2000): Characterization of particulate materials. Powder Handling \& Processing, 12 (4), pp. 355-363. 
